\title{
URBAN STRUCTURE AND ECONOMIC GROWTH
}

\author{
Peter Gordon and Harry W. Richardson* \\ University of Southern California \\ Los Angeles, CA 90089-0626
}

To be presented at the $49^{\text {th }}$ Annual Meeting of the Western Regional Science Association Sedona, Arizona

February 21-24, 2010

*Dr. Bumsoo Lee of the University of Illinois contributed to the discussion on pages 18-21. A version of this paper will be published in the Oxford University Press Handbook of Urban Economics and Planning 
"It is one of the ironies of the age. Just as the wonders of communications technology make it possible to conduct all sorts of computer-based activities from any corner of the earth, so humanity clusters more into cities than ever before. Location, which should surely be irrelevant, seems to matter more, not less. Physical proximity appears to have virtues in commercial life that no amount of technological gimmickry can replace."

The Economist (July 16, 2001)

\section{INTRODUCTION}

Adam Smith was one of the first to call attention to economic growth differences among nations.

He described how the workings of markets, specifically the extent of specialization in production, offer a plausible explanation of these differentials. This idea has been enriched over the years with the insights of Joseph Schumpeter, F.A. Hayek, Douglass North, and many others.

Schumpeter highlighted the notion of the entrepreneur as the prime mover in markets. Acts of successful discovery underlie the dynamics of economic growth. Hayek elaborated that a market that generates opportunity cost signals makes it possible for large numbers of strangers to coordinate all the efforts that implement the entrepreneur's vision.

Research in recent years has re-emphasized the importance of institutions (usually involving clear and credible property rights, freedom from expropriation, unimpeded markets and minimal government) that best poise entrepreneurs to succeed (see Ricketts, 2008, for an up-to-date overview $)^{1}$. In this paper, we survey recent work in urban economics and suggest that its challenge is to explain how entrepreneurs and others can be spatially poised to succeed. Just as Douglass North taught us that institutions matter, we describe how cities matter.

\footnotetext{
${ }^{1}$ This was the topic of the 2009 Presidential Address to the $121^{\text {st }}$ meeting of the American Economic Association (Dixit, 2009).
} 
We argue that favorable institutions make it possible to get favorable spatial arrangements and both of them are essential to economic growth.

Modern theories of economic growth are influenced by Schumpeter's ideas as well as Solow's auspicious empirical finding that the growth of inputs alone does not satisfactorily explain the growth of output. This has prompted investigations of technological change and the extent to which it is embodied in labor and capital. The former gave rise to studies of the importance of human capital and the "knowledge economy." Several papers by Glaeser and his colleagues demonstrate the link between human capital and urban success. Cities with a higher percentage of college educated citizens grow faster. In recent work, Moretti (2003) has investigated human capital spillover opportunities that are made possible by urbanization.

These results hint at the important idea that the spatial arrangements of labor and capital matter. Transactions costs have a spatial dimension. There are also external costs and benefits not involving transactions, many of which (including the exchange of non-codified ["ambiguous" in Mills' formulation] information) also attenuate with distance. ${ }^{2}$ In what follows, we find it useful to distinguish between potential and realized externalities. The available technology explains the potential externalities, but only some of these are realized once locations are chosen. Potential positive and negative externalities decline with distance, but as the costs of overcoming distance fall, the benefits are available across ever larger distances, helping to explain the spreading out of cities. When we ask "Why are there cities?" we are immediately pointed to the idea that spatial arrangements emerge whereby the benefits exceed the costs. Otherwise, why

\footnotetext{
${ }^{2}$ Audretsch and Feldman (2003) emphasized the spread and accumulation of new knowledge.
} 
would anyone pay land rents? In fact, there is substantial evidence of systematic spatial variations of wage capitalization as well as rent capitalization. It follows that many households as well as firms find themselves at locations where positive realized externalities dominate negative realized externalities. As in other areas of economics, competition favors better outcomes, in this case congenial urban structures and the set of realized agglomeration economies made possible. Many "market failures" are mitigated because various externalities are mediated in the urban land market. ${ }^{3}$

F.A. Hayek emphasized the complexity of production, the indispensable nature of local knowledge and the emergence of spontaneous order. There is cooperation between a very large numbers of strangers, all responding to market prices. But he did not consider how land prices and land markets augment all this. Jane Jacobs did recognize "the intricate social and economic order under the seeming disorder of cities" (1961, p. 15). Chris Webster and Lawrence Lai (2003) went further, singling out the "spatial order" of evolving cities as one of five spontaneous orders.

Site planning is carried out by developers and planners on innumerable occasions and wonderfully clever and pleasing arrangements often emerge. The rent-maximizing owner of a shopping mall typically creates designs that maximize shopper convenience and, therefore, rental income. However, many planners and urban designers hold the view that they have it within their grasp to create metropolitan-wide plans based on a "vision" of how development should proceed. Sharp contrasts between achieved performance vs. the ambitions of the $20^{\text {th }}$ century

\footnotetext{
${ }^{3}$ Our interest in agglomeration concerns how it interacts with the nature of cities. The New Economic Geography recognizes the importance of distance vis a vis interregional specialization and exchange, but when it come to cities it recognizes space and distance only with respect to workers' access to jobs (Head and Thierry, 2003).
} 
new cities (e.g. Abuja, Brasilia, Canberra, Chandigarh, New Bombay, Ciudad Guayana) are well known and illustrate the hubris of what Hayek famously described as the "fatal conceit".

Because cities are "emergent orders," we can see that they are "the engines of growth" (Lucas, 1988). This is where human capital flowers. The many authors who have alluded to this idea are discussed by Baldwin and Martin (2004. However, implicit in these discussions is the key idea that cities must generate and sustain successful location patterns. However, these are a moving target. Favorable spatial arrangements are required to facilitate the uncountable number of entrepreneurial acts of discovery and coordination that foster economic growth. Growth also creates the opportunity for newly efficient spatial arrangements.

There are good reasons to believe that urban form matters to economic growth. The rest of this paper discusses recent research that has provided some basic insights and evidence. However, policy discussions that presume planners can and should attempt to reorganize urban structure can be challenged. 


\section{AGGLOMERATION AND GROWTH}

Several types of agglomeration economies (shared inputs, labor market pooling and knowledge spillovers) were first identified by Marshall (1890). Urbanization mitigates many direct transactions costs. Marshall also emphasized the transactions costs that involve third parties (shared inputs and labor market pooling) as well as benefits (spillovers) that occurred without transactions. Knowledge spillovers are clearly an important part of Marshall's third category, but these do not necessarily involve transactions and are, therefore, not addressed by the New Economic Geography, which concerns itself with "pecuniary” externalities and which ignores land markets. Yet, our analysis helps to shed light on how and why such spillovers can become pecuniary and that this requires land markets. ${ }^{4}$ Over time, there is also path-dependency which can be seen as an inter-temporal agglomeration effect. ${ }^{5}$

Turning to the challenge of corroborating these ideas, if cities matter to economic growth, which attributes of cities should be examined? Alonso (1971) was among the first to call attention to the general relationships among city size, congestion costs and agglomeration benefits. Costs rise at an increasing rate while the benefits increase at a decreasing rate. This is a static view that suggests the idea of an optimal city size. However, over time, the spatial ambit of many (potential) agglomeration economies can increase and the diffusion that results can mitigate congestion effects. Nevertheless, size can be a reasonable proxy for variety and heterogeneity as elaborated by Quigley (1998), who organizes his discussion of urban agglomeration as falling

\footnotetext{
${ }^{4}$ We do not concern ourselves with the question of whether or not there is anything "new" in the New Economic Geography. That question is discussed by Ottaviano and Thisse (2004)

${ }^{5}$ Recent work on the formal treatment of agglomeration and economic growth is summarized in Baldwin and Martin (2004)
} 
under four headings: (i) scale economies internal to the firm; (ii) shared inputs between firms; (iii) transactions cost economies in production (example: labor market matching); and (iv) "statistical economies" involving transactions among third parties. It is not clear to us where human capital spillover effects would fit. The well known demand for face-to-face interaction as ideas are shared is the obvious example. Durlauf (2004) has placed William Julius Wilson's labor market networking opportunities in the broad category of "neighborhood effects."

The literature on externalities has differentiated between "pecuniary" externalities that show up as price effects vs. "technological" externalities that do not involve any transactions. However, our discussion of externalities in the context of land markets obviates this. Efficient land markets prompt land use arrangements whereby selected potential externalities are realized and capitalized in land rents, making them pecuniary and adding them to the set of price signals available to locators. Hedonic analysis of land values has been used to identify their various components. These highlight the values attached to site characteristics, including access to valued activities. Bidders for sites consider different benefits available at any site; some of these involve reduced access costs to activities with which transactions are planned while others involve better access to activities and services that do not involve explicit transactions, such as better public schools. At the same time, sites are valued for their distance from negative externalities that can be avoided by choosing the site. All realized externalities become pecuniary externalities. This is because land markets guide resources via signals that refer to all possible benefits and costs available at alternative sites. As long as land market is recognized in the analysis (and as long as information problems are overcome), all externalities are pecuniary. ${ }^{6}$

\footnotetext{
${ }^{6}$ This statement includes the idea of extraordinary consumption possibilities in "super-cities" (Todorovich, 2007).
} 


\section{EVIDENCE: POPULATION AND EMPLOYMENT TRENDS}

A simple analysis of city size distribution trends highlights the timeline of population suburbanization in the U.S. Table 1 shows the population shares of the largest cities through the $20^{\text {th }}$ century. The shares accounted for by the largest 20 or the largest 75 cities rose through 1930, but then declined steadily. Of course, almost all cities annexed some territory over the years. Our discussion suggests that both trends (up to and since 1930) represent the influence of agglomeration forces. Activities coalesce in pursuit of agglomeration opportunities, but they now do this over a larger spatial area to avoid some of the costs of congestion when and if this is possible. In the later period, it was apparently possible to reap the benefits of size while being beyond the city limits but within the greater metropolitan area. Table 2 hows population shares over time using the Census Bureau's Urbanized Areas (UZAs). These do not follow political boundaries but refer to functional economic areas that are adjusted as development spreads. Also in this case we consider the same top 24 areas for all years (only the same top 24 appeared in all six Census enumerations). We also show the population shares of the traditional central city of each UZA. Again, central city population shares declined continuously, while UZA shares grew continuously. Activities continued to gravitate to the top areas, but this can only be observed if these places are defined each year in terms of growing footprints.

Turning to employment trends, the U.S. auto industry provides the example of early and later versions of agglomeration opportunities in the early 20th century. The industry clustered (near Detroit) in the early years, but in the late $20^{\text {th }}$ century, new auto plants spread over many states, 
especially in the U.S. South. ${ }^{7}$ The role and the nature of agglomeration economies in this industry have apparently changed. As a result, some regions have become less specialized. However, agglomeration economies can occur within firms or between firms in the same industry or between firms in different industries. The success of Boston's Route 128 and Silicon Valley indicate increased specialization in these regions, but can be ascribed to either or both types of agglomeration economy.

Glaeser et al. (1992) considered modern endogenous growth theory in a spatial context as suggested by the work of Jane Jacobs. Their findings support the importance of local competition and variety rather than simply industrial concentration. Cross-industry effects of proximity are compared to within-industry spillovers. The authors ask whether growth is faster in industry-city combinations when these have been there for some time. Are the agglomeration benefits important only in the early stages of growth? Is there faster growth in places where an industry is over-represented or where it is under-represented? They find that diversification rather than specialization contributes most to growth. Knowledge spillovers are most valuable among industries.

Dumais, Ellison and Glaeser (2002) reported evidence of significant localization and agglomeration economies among firms in the same industry. Henderson (1994) tried to assess the relative importance of the four possibilities: static-between firms in the same industry; staticbetween firms in different industries; dynamic-between firms in the same industries; and dynamic-between firms in different industries. In the Rosenthal-Strange (2003) survey of the literature of ten recent empirical studies, they find evidence in support of urbanization and

\footnotetext{
${ }^{7}$ This point was made by Krugman (2009).
} 
localization and diversity (Jacobs) economies. These categories describe the range of parties involved, but the authors also emphasize that the geographic and temporal scope are also of great interest. Henderson (1994) found evidence for localization as well as urbanization economies. He also presented strong evidence of dynamic externalities that are realized over years and reports a five-year lag before the full effect of externality benefits are experienced.

Discussions of spatial scope and the continuing spatial decentralization of people and jobs suggest that the old dichotomy between urban and regional analysis is no longer adequate. The U.S. Census Bureau has recognized this and introduced the concept of the Micropolitan areas to better describe the "edge cities" phenomenon. We used the BEA's Regional Economic Information System (REIS) 35-year county-level time series. We aggregated counties to recognize the new reporting areas and found that decentralization trends are much more profound than simply a "move to the suburbs."

Tables 3 and 4 show long-term growth trends in population and private employment between 1969 and 2004 by urban hierarchy size class and U.S. Census Division. Data for all counties are aggregated to the core-based and non-core-based categories. The former are metropolitan (at least 50,000 population) or micropolitan (at least 10,000 population, but less than 50,000 ); the metropolitan areas are groups of metropolitan counties and are either "large" meaning more than one-million population in 2000 or "small" meaning less than one-million; micropolitan counties are classified as adjacent to either type of metropolitan area or neither ("non-adjacent"). The micropolitan category represents the Census Bureau's attempt to track the performance of "Edge 
Cities." The remaining "non-core based" areas counties are also either adjacent or not adjacent to a core-based county. ${ }^{8}$ When we look for growth leaders among these categories, there are significant variations by Division. The large metropolitan areas rank first in population growth only in the West North Central, South Atlantic, West South Central Divisions, where large urban areas are likely to be relatively "young". Otherwise, the adjacent-to-large-metro Micropolitan Areas lead in four of the nine Divisions (except for the case of Mid-Atlantic and East North Central, where the most remote areas are the growth leaders. Private sector employment growth patterns are somewhat similar. The large metropolitan areas are growth leaders in three of the Divisions, South Atlantic, West South Central and Mountain. Again, these would not be the older of the large cities. Otherwise, the growth leaders are the smaller metropolitan areas (MidAtlantic and West North Central) of the adjacent-to-large-metro Micropolitan areas (for the New England, East South Central or Pacific Divisions. Non-core base counties lead in the MidAtlantic and East North Central Divisions. These job growth data suggests that the era of the "bedroom" suburbs is largely over. The suburbs and beyond are where many jobs are created. Agglomeration economies have a larger spatial ambit than ever.

Several researchers have suggested that metropolitan population densities rather than metropolitan size (population or employment) is the variable that is more representative of agglomeration opportunities (Ciccone and Hall, 1996; Harris and Ionnides, 2000). Carlino (1990) showed that the densely settled counties exhibited slower population and employment growth. Density prompts congestion costs and these inhibit growth. A general result is that a doubling of population density increases productivity by about six percent. However, results such as these are` unsatisfactory because of the obvious problems whenever a mean value from a distribution

\footnotetext{
${ }^{8} \mathrm{http} / / /$ www.census.gov/population/www/metroareas/metroarea.html
} 
with considerable variance is thought to be an important indicator. 9 "Population density has been identified by many analysts as a key indicator of the efficiency and sustainability of human development patterns," writes the Lincoln Institute's Gregory Ingram. The statement is true enough, but still relies on the average density measure. Transactions opportunities involve pairs (or larger sets, including third parties) of activities and are impacted to the extent that they occupy peculiar pairs (or larger sets) of locations. And, as our discussion of realized externalities suggests, it is the specifics of location patterns that matter.

A recent report from Brookings (Kneebone, 2009) documents “job sprawl” in major metropolitan areas. In this case, the authors study employment by zip codes. They report large shares of metro area jobs more than 10 miles from the city center. They report that "[o]nly 21 percent of employees in the top 98 metro areas work within 3 miles of downtown, while over twice that share (45\%) work more than 10 miles from the city center."10 Relying on data from sub-metro areas represents an improvement. Nevertheless, there are still very few studies that have examined sub-city/sub-metro spatial detail. This is not surprising because spatially detailed data are less available and much more difficult to work with. Giuliano et al. (2009) developed a case study of the Los Angeles metropolitan area in which they track sub-center employment growth from 1990 to 2000 . Testing for the determinants of sub-center growth, they find that the generalized accessibility measures play at best a minor role.

Most studies of metro area efficiency have addressed possible commuting economies. They consider agglomeration and growth only indirectly. Are commuting economies or diseconomies

\footnotetext{
${ }^{9}$ In our view, the mega-region studies (see for example Florida, et al., 2007) point in the wrong direction by suggesting even greater spatial aggregation.

${ }^{10}$ Kneebone et al. (2009), p.1.
} 
linked to urban size or urban structure? There are many such studies and, to the extent that they shed light on our concerns, we report on them separately in the next section. 


\section{EVIDENCE: THE SPRAWL DEBATE AND COMMUTING STUDIES}

Commuting economies were the lens through which economists first studied the spatial organization of cities. Alonso began by adapting von Thunen's model of agricultural land use to the study of urban land use. This approach gave rise to a more sophisticated, if unrealistic, literature on equilibrium models of monocentric cities. The efficiency properties of equilibrium were of particular interest.

The monocentricity assumption was embraced by urban economists because it availed itself of mathematically tractable models of urban structure and growth. Until recently, most urban economic models rested on the monocentricity assumption. Most early challenges came from observers not wedded to analytical models. Garreau (1991), in particular, wrote about Edge Cities and elaborated the simple idea that airports were the new hubs for business development and they were not to be found in urban centers. But analysts interested in commuting economies were the ones compelled to measure degrees of polycentrism and generalized dispersion. The commuting economies and general viability of these forms became a major issue of interest.

Many current discussions of urban structure are inspired by policy discussions of possible inefficiencies. This has come to be known as the sprawl debate. Air quality and highway congestion are on people's minds, but congestion pricing (or emissions charges) on roads and highways has not been widely implemented and planners have instead looked for second-best policy measures, including the planning regulations and measures to rearrange land uses. These ideas have found a large and sympathetic audience among those critical of suburban 
development. William Whyte was an early critic, writing about urban sprawl in The Explosive Metropolis as early as 1958 Since then, antipathies to automobiles, low-density suburbs and middle class lifestyles have become an international political staple. ${ }^{11}$ Managed Growth, New Urbanism, Slow Growth, Smart Growth, Sustainability Planning, Urban Containment, and Urban Growth Boundaries are some of the banners under which plans that challenge market trends have been promoted. It is revealing, however, that the effects of these efforts to reverse dominant urban trends have been modest, if not negligible, regardless of where implemented.

The 1974 Costs of Sprawl study generated considerable interest and controversy. However, this was only a comparison of five prototypical types of urban development. The results were soon identified as suspect (Althsuler, 1977, Windsor (1979)), but were nevertheless welcomed by anyone ready to challenge widespread suburbanization. Burchell (1998) cited more plausible comparisons, but many of these were also simulations. Ladd's work (1992) stands out because it was empirical. She studied expenditures for local services and found an inverted U-shaped relationship between the density of development and infrastructure costs, first rising and then declining. There has been some commentary about the social costs of sprawl, much of it more rhetorical rather than analytical, but Downs (1999) found no relationship between sprawl and indicators of central city decline. Another often referred to social cost is "spatial," the hypothesis that low income and minority workers lack access to suburban jobs that are growing faster because of sprawl. We found no convincing evidence for this hypothesis many years ago (Gordon, Richardson and Kumar, 1989). There have been many studies since then reaching a

\footnotetext{
${ }^{11}$ Many commentators have been keen to link almost any social pathology to suburban development. Kunstler saw "a system that corrodes civic life, outlaws the human scale, defeats tradition and authenticity and confounds our yearning for an everyday environment worthy of affection. (The Atlantic, September, 1996, p. 43). In a similar vein, The Atlantic's "Divided We Sprawl” (1999)
} 
variety of conclusions. However, whatever the arguments supporting spatial mismatch, the empirical case is weaker than it was in 1989 because of the survival of low-income, unskilled service jobs in the core city supporting the producer services economy, the suburbanization of some low-income households, the opening of new transit and bus lines, and rising automobile ownership among the relatively poor. As for the economic and social benefits of alternative spatial arrangements, there has been very little research, possibly because most of these benefits fall into the "intangibles" category. A comprehensive cost-benefit analysis remains to be undertaken. A growing body of recent research by urban economists directly addresses the antisprawl critics. Glaeser and Kahn (2003) argue that:

First, despite the pronouncements of academic theorists, dense living is not on the rebound. Sprawl is ubiquitous and expanding. Second, while many factors may have helped the growth of sprawl, it ultimately has only one root cause, the automobile. Third, sprawl's negative quality of life impacts have been overstated. Effective vehicle pollution regulation has curbed emissions increases associated with increased driving. Fourth, the problem of sprawl lies not in the people who have moved to the suburbs, but those who have been left behind. The exodus of jobs and people from the inner cities have created an abandoned underclass whose earnings cannot support a multi-car based lifestyle (p. 2).

The urban historian Robert Bruegmann (2005) notes that "sprawl" is a very old and almost universal phenomenon. ${ }^{12}$ He also notes its acceleration in recent years as a consequence of increasing affluence. Middle class families (perhaps formerly "working class") can live in ways

\footnotetext{
${ }^{12}$ The details of the U.S. history of suburbanization are elaborated at length in Jackson (1985).
} 
that were once reserved for the wealthy, consuming space, safety, greenery and cleaner air. He notes that:

Most American anti-sprawl reformers today believe that sprawl is a recent phenomenon caused by specific technological innovations like the automobile and by government policies like single-use zoning or the mortgage interest deduction of the federal income tax. It is important for them to believe this because if sprawl turned out to be a long-standing feature of urban development worldwide, it would suggest that stopping it involves something much more fundamental than correcting some poor American land use policies.

Auto-oriented development may have taken hold on a large scale in the U.S. first. However, as incomes in other countries began to catch up in the post-World War II years (and in the postCold War years in more countries), a growing middle class demanded (and obtained) automobility and most cities have had to change. The personal freedom of solo auto travel has great appeal. In addition, as there are more two-worker households, trip-chaining has grown, further highlighting a level of convenience that no other transport mode can match. This is now a global phenomenon as more countries around the world experience a growing middle class. This has all occurred in spite of anti-auto policies, especially in Western Europe. U.S. policy makers have been trying to mimic these, especially with respect to massive subsidies to public transit, but these have also been ineffective. Plotting the transit ridership share and transit subsidies, it can be seen that they move in opposite directions showing that these subsidies have failed to 
achieve their major goal of reducing the automobile's mobile share (Figure 1$)^{13}$. Table 5 shows the prevalence of suburbanization in different regions of the world. Thus, suburbanization and decentralization are ubiquitous, despite the wide variety of urban planning policies, regulations and institutions from country to country. Policy differences seem not lead to outcome differences, and preferences trump policies. There is an argument that residential preferences in the United States are changing primarily because of demographic factors (e.g. aging, childless households); if that became more the norm rather than a modest niche demand, preferences and prevailing policies might become more aligned.

Most of the empirical research has sought to identify commuting economies or diseconomies associated with various spatial arrangements. Commuting costs are given much more attention than all other costs of settlement. There are several reasons for this. First, efficient matching of people to jobs is clearly desirable. This matching is inevitable in light of the trade-offs that agents make with respect to their other accessibility demands. Second, there are well known external costs to automobile commuting. Is compact development efficient in terms of work travel? The unwillingness to price the external costs of travel has spawned the idea that policy makers should try to change urban structure. The third reason for the focus on commuting is probably the relatively easy ${ }^{14}$ availability of commuting data, some of it at the sub-metropolitan scale.

A standard objection is the idea that suburbanization leads to more travel. However, this is based on a false premise. Most suburbanites do not drive much more than central city residents. The

\footnotetext{
${ }^{13}$ Subsidies to transit include cross-subsidies from the federal fuel tax, 20 percent of which is diverted to public transit.

${ }^{14}$ The larger metro areas with regional planning agencies usually purchase CTPP data from the U.S. Census Bureau.
} 
error arises from a misunderstanding about the proportion of suburban residents who work downtown and in central cities. The 2000 census reported that 41 percent of all commuting was suburb-to-suburb (only 17 percent was suburb-to-central city; much less was suburb to downtown) and between 1990 and 2000 suburb-to-suburb commuting grew by 64 percent, far surpassing the growth of any other commuting segment (Pisarski, 2007). Moreover, the work trip is only a small proportion ( 23 percent) of total VMT (vehicle miles traveled).

The associated assumption that the relationship between VMT and air pollution is linear is problematic. Leaving aside the wide variation in emissions by vehicle size and type, the most important point is that air pollution costs are much more closely related to population densities because the vast proportion of air pollution damages is human health costs and these are a function of the people living in a particular area. Because central city densities are much higher than suburban densities, air pollution costs are much higher in central cities than in suburbs, and this is compounded by the higher levels of traffic congestion in the central city. ${ }^{15}$

Perhaps the most interesting finding from research on cities and traffic is that the costs of transportation do not increase as fast as population. This is especially true for time costs, which are overwhelmingly the most important user cost. The result is not surprising because there is some rationality in how land markets work. Employees and employers tend to choose locations that do not put them out of reach of each other. There are examples of outlier commutes that make the news, but these are not the norm and are usually explained by peculiar situations. What is most relevant, however, is the experience of the most commuters and non-work tripmakers. These findings are all the more remarkable because the auto-highway system is

\footnotetext{
${ }^{15}$ Schweitzer and Zhou (2009) elaborate the complexity of the density-air quality relationship.
} 
poorly managed. Most politicians and policy makers are still reluctant to implement peak-load pricing or other types of tolling. Free access overwhelms any facility. This means that crowding has become the default rationing mechanism on most roads and highways. Traffic problems should surprise no one. Traffic doomsday is forever impending but never arrives. The academic literature has demonstrated these results many times. Some of these findings are briefly summarized in this paper.

Substantial research in this field rests on aggregate regression analysis in which metropolitan areas are the units of analysis. These studies typically regress average commuting time on various socio-economic variables, transportation infrastructure descriptors and some measures of urban spatial structure such as population and employment densities, the extent of centralization or polycentricity, and jobs-housing balance or regional level accessibilities. Izraeli and McCarthy (1985) was one of the earliest cross-sectional analyses; they examined the commuting time effects of population density in 61 U.S. metropolitan areas. They found that density is associated with longer average commuting times after controlling for other socio-economic variables. Gordon et al. (1989) tested additional urban spatial structure variables and found that mean commute times by automobile driving increased with residential and commercial densities but decreased with industrial density. The employment share of the core city in each metropolitan area was also associated with longer average commute times. These findings suggest that employment decentralization and dispersion contribute to reducing commuting times. Crane and Chatman (2003) tested the impacts of employment suburbanization by industry using commuting distance data from the American Housing Survey (a less common but perhaps a more valuable source than the Census of Population and the National Household Travel Survey). They also 
found that overall employment suburbanization is associated with shorter commuting lengths, although some weak opposite effects were found for some industrial sectors such as manufacturing and finance.

In an intertemporal study, Kahn (2008) found that: "Overall, the urban size effect of commuting times is surprisingly stable between 1980 and 2000." He also reported that the effects of population size on congestion are highest in the older cities of the Northeast. "The compactness of Northeast cities increases congestion, bottlenecks, pollution exposure externalities and more interactions between strangers [one of the causes of crime that he describes] than in cities in other regions." Kahn conducts a variety of statistical tests that highlight the role that employment decentralization in the major metro areas has played in helping suburbanites to experience shorter commutes.

Other studies have elaborated measures of metropolitan spatial structure beyond density and decentralization. Ewing et al. (2003) examined the traffic congestion effects of four sprawl indices that they constructed via principal components analysis using rich land use data inputs. Denser and finer street layout was associated with a longer commuting times and higher congestion levels while residential densities were not significant. Their set of explanatory variables, however, excluded automobile ownership. This omission of a key explanatory variable probably explains the seeming explanatory power of the variables they did include. On the other hand, mixed land uses contributed to reducing commuting times and the degree of centering was associated with less congestion. Sarzynski et al. (2006) advanced this crosssectional approach in several ways. First, they developed diverse and more elaborate urban form 
variables - various sprawl indices including density, continuity, concentration, centrality, proximity, mixed use, and nuclearity. Second, their regression model addressed potential endogeneity and time-lag effects between urban form variables and traffic congestion. Finally, they used extended urban areas (EUAs), an even more appropriate geographical unit of analysis than the metropolitan area. The latter are counties, many of which included considerable undeveloped space. The authors found that density/continuity factors and housing centrality were associated with higher congestion after controlling for congestion levels ten years previously. Housing-job proximity was negatively related with commuting times.

The results of the cross-sectional studies are mixed. While lower density and employment decentralization were generally associated with shorter commuting times in earlier studies consistent with the "co-location" hypothesis, the links became less significant in more recent studies. Gordon et al (2009) reported that the suburbanization traffic "safety valve" was overwhelmed in the late 1990s when rising per capita incomes (and increased auto ownership and trip making coincided with reduced road building.

However, the widely held belief in the planning community that decentralization or sprawl is a key factor explaining increased commuting times is not supported by empirical evidence.

Lee's recent study (2006) is perhaps the most detailed and the most compelling. He studied the 79 largest U.S. metro areas and compared commutes with job location in each area. Figure 2 shows how average commuting times vary with metropolitan population. There are advantages associated with polycentric structures and jobs dispersion in large metropolitan areas. The first 
panel shows a linear relationship between average commuting time and the natural log of metropolitan population size.

In a multivariate analysis, Lee found that a doubling metro area population size results in average commute time increases of approximately 2.2 minutes. However, the commute time penalty of metro size is much larger for CBD workers (6.1 minutes) and smaller for workers in subcenters (2.9 minutes) and dispersed locations (2.0 minutes). The minimal effect of metro size on average commutes is due to the outliers, the relatively few workers that have jobs or housing at distant locations.

These relationships hold up when control variables are added to the analysis. Recent work by Lee and Gordon (2007) looks for the urban growth effects of spatial structure via its impact on commuting; growth is the most easily accessible proxy for productivity. The finding is that urban forms evolve to accommodate growth; spatial patterns emerge that accommodate and limit the road and highway congestion that comes with greater urban scale. This view places a premium on flexible land markets and the open-ended evolution of urban structure. Dispersion and jobs sprawl is more likely to be the traffic solution than the traffic problem in large metropolitan areas. In fact, problems are intensified when downtowns and central locations gain in size. This makes sense in light of our understanding of how land markets work. It is standard practice to model traffic flows to reflect adjustments to temporary disequilibria; but land markets are similarly a dynamic process energized by various disequilibria. This view also undermines conventional wisdom that naively links more development to more traffic. 
The agglomeration economies literature and the studies of commuting economies are linked because both address the question of economically efficient spatial arrangements. Any study of the costs of any aspect of development is interesting, but these must be seen in perspective because cost minimization is never the bottom line. Both areas of investigation pay very little attention to the regulatory environment. Bertaud (2004) reminds us that cities are formed in the real world of the second-best. "Urban structures are shaped by market forces interacting with regulations, primary infrastructure investments and taxes" (p. 1).

Planners and developers were the original supporters of zoning in the U.S. as they saw it as a way to protect the value and exclusivity of single-family homes. Edwin Mills was one of the first to report that urban land use controls have been used much more for exclusionary purposes than to control externalities. Large-lot development requirements are widespread and add significantly to housing costs. ${ }^{16}$ Highly regulated land markets also had the effect of reducing housing affordability and creating housing price bubbles in various metro areas. Glaeser and Gyourko (2008) note that, "In well-functioning markets, both price and quantity can adjust to changes in demand conditions. In supply-constrained markets, most of the adjustment occurs in the price of housing because stringent land-use regulations make it too costly to change the quantity of housing very much."17

\footnotetext{
16 “Are Housing Requirements Excessive?" HUD User (April, 2008).

${ }^{17}$ Glaeser and Gyourko (2008), p. 3.
} 
Justifying the "homevoter" view of local governance, Fischel (2004) cites discussions that explain zoning as an alternative to non-existent home value insurance. As incomes rise, homeowners' view of how much of their local environment matters to them expands. However, this can also prompt a NIMBY (Not In My Backyard) approach that is used to block any local development. In addition, we now have "sustainable development" and "smart growth" platforms that also advocate strong land use controls. However, these are often vaguely defined and result in alliances between environmentalists and developers unable to escape limited density development restrictions.

Epstein (2008) also notes the negative effects of restrictive land use regulations. Unless checked, special interests can be expected to have their way; Epstein also finds an alliance between interests with an anti-competitive agenda and others with environmentalist leanings. In many places, land use policy to limit nuisance externalities has become a full-fledged economic development policy. An unintended result has been has an increased willingness to use eminent domain powers to condemn private land uses for private development (the well known Kelo v. City of New London case, Epstein (2008)).

Regulations distort land values, substantially raise housing costs and make development more difficult. Similarly, land assembly in most cities has become harder to achieve. Developers prefer to move ahead with large projects if they have the city and perhaps other stakeholders on their side. The U.S. Supreme Court's position on takings was further made explicit in Kelo when the court affirmed that the city's plans for economic development fell within the Constitutional requirement that private property could only be taken (with compensation) if a "public purpose" 
was to be met. Epstein argues that large urban real estate developments go ahead when "City Hall" is on the side of the developer; land assembly and permitting is too costly without this official and often community assistance.

Finally, land use policy is not a matter of sacrificing efficiency for the sake of equity. In the 1970s, Alonso noted that: “(1)ocal policies to limit population are probably not very effective, and when they are effective they are regressive and counter-productive in terms of social well being” (1973, p. 191). Edward Banfield made a similar point ten years later: "the upward mobility on the part of disadvantaged persons in the cities has been, is being, and undoubtedly will be hampered by laws and regulations the manifest purpose of which is to make them better off' (1982, p. 339), we reported similar outcomes in Richardson et. al,1993 ${ }^{18}$. Growth controls have disparate impacts.

Bertaud's world of the second-best has not been a disaster in terms of economic development: the long-term economic growth of the U.S. over the last 125 years has been at an annual rate of 1.8 percent. That implies more than a nine-fold increase in real per capita income. If 30 years define a generation, then in each generation material wealth has more than doubled.

The data in Figure 3 support the argument about the positive aspects of urban development. Per capita income growth has tracked productivity gains and these have tracked urbanization (the share of population in urbanized areas) since at least 1950. This discussion has elaborated these 
linkages by calling attention to the relationship between idea-driven growth and urbanization (Jones 2002). 


\section{CONCLUSIONS}

Accelerated economic development over the last 250 years has prompted economic historians to investigate "the greatest discontinuity in human history" (Lindsey, 2007). ${ }^{19}$ They have focused on how favorable institutions are developed, meaning those that enable agents to engage in successful discovery and innovation. These institutions have evolved over many years. Favorable spatial arrangements are more likely to lead agents to success.

However, this occurs in the world of second-best. The evidence presented suggests that the second-best has been surprisingly benign. In fact, Leamer (2009) has emphasized that the U.S. economy has been on a steady growth path, averaging three percent GDP per capita expansion per annum over the last 30 years. Over the last 100 years, there has also been steady growth with fluctuations within a narrow band (Figure 4). Cities in the developed countries facilitate prosperity. The world changes rapidly in the era of globalization but most of the urban sector adjusts to the challenge. Can planners and policy makers accept the idea that they are not the prime movers in this process?

We have called attention to the underestimation of urban structure as a factor in affluence. How producers and consumers arrange themselves in space makes a difference. Remarkably, even in a second-best world, spatial patterns emerge that facilitate efficiency and growth. Unfortunately, so many prescriptions for how cities can be better managed are accompanied by assertions (with very little evidence) that compact spatial arrangements are superior. 
Table 1: Populations (in millions) and Shares of Largest U.S. Cities, 1900-2000

\begin{tabular}{lccccccccccccc} 
& 1900 & 1910 & 1920 & 1930 & 1940 & 1950 & 1960 & 1970 & 1980 & 1990 & 2000 \\
\hline NYC & 3.437 & 4.767 & 5.620 & 6.930 & 7.455 & 7.892 & 7.782 & 7.895 & 7.072 & 7.323 & 8.008 \\
TOP 20 & 11.971 & 15.710 & 19.487 & 23.897 & 25.026 & 27.516 & 28.092 & 28.619 & 27.304 & 28.538 & 30.944 \\
TOP 75 & 16.766 & 22.439 & 28.101 & 34.444 & 36.178 & 40.748 & 43.977 & 46.054 & 44.645 & 47.134 & 53.467 \\
US & 76.094 & 91.973 & 106.461 & 123.293 & 131.954 & 151.325 & 179.979 & 205.052 & 227.225 & 243.464 & 282.224 \\
NYC SHARE & $4.5 \%$ & $5.2 \%$ & $5.3 \%$ & $5.6 \%$ & $\underline{5.65 \%}$ & $5.2 \%$ & $4.3 \%$ & $3.1 \%$ & $3.1 \%$ & $2.9 \%$ & $2.18 \%$ \\
20 SHARE & $15.7 \%$ & $17.1 \%$ & $18.3 \%$ & $\underline{19.4 \%}$ & $19.0 \%$ & $18.2 \%$ & $15.6 \%$ & $14.0 \%$ & $12.0 \%$ & $31.4 \%$ & $11.0 \%$ \\
75 SHARE & $22.0 \%$ & $24.4 \%$ & $26.4 \%$ & $\underline{27.9 \%}$ & $27.4 \%$ & $26.9 \%$ & $24.4 \%$ & $22.5 \%$ & $19.6 \%$ & $18.9 \%$ & $18.2 \%$ \\
\hline
\end{tabular}

Source: U.S. Census 
Table 2: Populations and Shares of Largest U.S. Urbanized Area and their Core Cities. 1950-2000

\begin{tabular}{|l|c|c|c|c|c|c|}
\hline & 1950 & 1960 & 1970 & 1980 & 1990 & 2000 \\
\hline New York & 7.892 & 7.782 & 7.895 & 7.072 & 7.323 & 8.008 \\
\hline Top 24 (in 2000) CCs & 26.318 & 27.774 & 28.797 & 27.012 & 28.309 & 30.034 \\
\hline Top 24 (in 2000) UZAs & 43.742 & 56.746 & 63.330 & 74.092 & 83.304 & 99.844 \\
\hline US & 151.325 & 179.979 & 205.052 & 227.225 & 249.464 & 282.224 \\
\hline & & & & $3.11 \%$ & $2.94 \%$ & $2.84 \%$ \\
\hline New York & $5.22 \%$ & $4.32 \%$ & $3.85 \%$ & $11.89 \%$ & $11.35 \%$ & $10.64 \%$ \\
\hline 24 CCs Share & $17.39 \%$ & $15.43 \%$ & $14.04 \%$ & $32.61 \%$ & $33.39 \%$ & $35.38 \%$ \\
\hline 24 UZAs Share & $28.91 \%$ & $31.53 \%$ & 30.87 & $32.61 \%$ & \\
\hline
\end{tabular}

Source: Authors' calculations from U.S. Census 
Table 3: Average Annual Population Growth Rates U.S. and 9 Census Divisions 1969-2004

\begin{tabular}{|c|c|c|c|c|c|c|c|c|c|c|}
\hline & & DIVISIONS & & & & & & & & \\
\hline & U.S. & $\begin{array}{c}\text { New } \\
\text { England }\end{array}$ & Mid Atlantic & East NC & West NC & $\begin{array}{c}\text { South } \\
\text { Atlantic } \\
\end{array}$ & East SC & West SC & Mountain & Pacific \\
\hline & & & & & & & & & & \\
\hline POPULATION & & & & & & & & & & \\
\hline Region & 0.0108 & 0.0055 & 0.0025 & 0.0041 & 0.0056 & 0.0173 & 0.009 & 0.016 & 0.0255 & 0.0172 \\
\hline Metropolitan & & & & & & & & & & \\
\hline Large & $0.0115(2)$ & $0.0041(6)$ & $0.0018(5)$ & $0.0040(5)$ & $0.0087(1)$ & $0.0198(1)$ & $0.0104(3)$ & $0.0224(1)$ & $0.0339(2)$ & $0.0162(5)$ \\
\hline Small & $0.0121(1)$ & $0.0064(5)$ & $0.0048(2)$ & $0.0038(6)$ & $0.0085(2)$ & $0.0174(2)$ & $0.0105(2)$ & $0.0139(3)$ & $0.0246(3)$ & $0.0205(2)$ \\
\hline Micropolitan & & & & & & & & & & \\
\hline Adj Lge Metro & $0.0110(3)$ & $0.0189(1)$ & $0.0041(3)$ & $0.0046(4)$ & $0.0078(3)$ & $0.0148(3)$ & $0.0137(1)$ & $0.0144(2)$ & $0.0387(1)$ & $0.0222(1)$ \\
\hline Adj Sm Metro & $0.0080(4)$ & $0.0098(3)$ & $0.0028(4)$ & $0.0040(5)$ & $0.0036(4)$ & $0.0126(4)$ & $0.0091(4)$ & $0.0054(5)$ & $0.0181(4)$ & $0.0160(6)$ \\
\hline Non-Adjacent & $0.0070(5)$ & $0.0083(4)$ & $0.0010(6)$ & $0.0050(3)$ & $0.0030(5)$ & $0.0091(5)$ & $0.0052(6)$ & $0.0073(4)$ & $0.0143(5)$ & $0.0163(4)$ \\
\hline Non Core Bas & & & & & & & & & & \\
\hline Adjacent & $0.0055(6)$ & $0.0113(2)$ & $0.0050(1)$ & $0.0051(2)$ & $-0.0011(6)$ & $0.0076(6)$ & $0.0055(5)$ & $0.0053(6)$ & $0.0143(5)$ & $0.0176(3)$ \\
\hline Non-Adjacent & $0.0029(7)$ & $0.0008(7)$ & - & $0.0105(1)$ & $-0.0049(7)$ & $0.0056(7)$ & $0.0021(7)$ & $0.0028(7)$ & $0.0066(6)$ & $0.0129(7)$ \\
\hline
\end{tabular}

Note: rankings for each column are in parentheses.

Source: "Regional Economic Information System 1969-2004,” Bureau of Economic Analysis, US Department of Commerce, U.S.

Census Bureau 
Table 4.: Average Annual Private Employment Growth Rates U.S. and 9 Census Divisions 1969-2004

\begin{tabular}{|c|c|c|c|c|c|c|c|c|c|c|}
\hline \multicolumn{11}{|c|}{ DIVISIONS } \\
\hline & U.S. & $\begin{array}{c}\text { New } \\
\text { England }\end{array}$ & Mid Atlantic & East NC & West NC & $\begin{array}{c}\text { South } \\
\text { Atlantic }\end{array}$ & East SC & West SC & Mountain & Pacific \\
\hline \multicolumn{11}{|c|}{$\begin{array}{l}\text { PRIVATE EMPL } \\
\end{array}$} \\
\hline Region & 0.0202 & 0.0149 & 0.009 & 0.0126 & 0.0189 & 0.0276 & 0.0203 & 0.0262 & 0.0393 & 0.0265 \\
\hline \multicolumn{11}{|l|}{ Metropolitan } \\
\hline Large & $0.0200(2)$ & $0.0136(7)$ & $0.0078(5)$ & $0.0119(7)$ & 0.0188 (3) & $0.0310(1)$ & $0.0223(2)$ & $0.0309(1)$ & $0.0445(1)$ & $0.0251(4)$ \\
\hline Small & $0.0221(1)$ & $0.0152(6)$ & $0.0129(1)$ & $0.0131(5)$ & $0.0220(1)$ & $0.0267(2)$ & $0.0220(3)$ & $0.0245(2)$ & $0.0396(2)$ & $0.0320(2)$ \\
\hline \multicolumn{11}{|l|}{ Micropolitan } \\
\hline Adj Lge Metro & $0.0186(4)$ & $0.0272(1)$ & $0.0111(3)$ & $0.0137(4)$ & $0.0209(2)$ & $0.0185(4)$ & $0.0251(1)$ & $0.0212(3)$ & $0.0363(3)$ & $0.0362(1)$ \\
\hline Adj Sm Metro & $0.0161(6)$ & $0.0187(4)$ & $0.0094(4)$ & $0.0126(6)$ & $0.0165(5)$ & $0.0178(5)$ & $0.0187(4)$ & $0.0146(6)$ & $0.0322(4)$ & $0.0222(6)$ \\
\hline Non-Adjacent & $0.0198(3)$ & $0.0206(3)$ & $0.0115(2)$ & $0.0174(2)$ & $0.0180(4)$ & $0.0233(3)$ & $0.0157(5)$ & $0.0172(4)$ & $0.0299(6)$ & $0.0273(3)$ \\
\hline \multicolumn{11}{|c|}{ Non Core Based } \\
\hline Adjacent & $0.0159(7)$ & $0.0229(2)$ & $0.0129(1)$ & $0.0150(3)$ & $0.0146(6)$ & $0.0157(7)$ & $0.0139(7)$ & $0.0150(5)$ & $0.0262(5)$ & $0.0244(5)$ \\
\hline Non-Adjacent & $0.0173(5)$ & $0.0184(5)$ & - & $0.0234(1)$ & $0.0120(7)$ & $0.0162(6)$ & $0.0145(6)$ & $0.0142(7)$ & $0.0244(7)$ & $0.0218(7)$ \\
\hline
\end{tabular}

Note: rankings for each column are in parentheses.

Source: “Regional Economic Information System 1969-2004,” Bureau of Economic Analysis, US Department of Commerce, U.S.

Census Bureau 
Table 5: Suburbanization Around the World

Share of Change in Population

\begin{tabular}{|c|c|c|c|c|c|}
\hline & Since & Areas & Core & Suburbs & Classification \\
\hline United States & 1950 & 52 & $8.4 \%$ & $91.6 \%$ & $\begin{array}{l}\text { Urbanized areas over } 1,000,000 \text { any } \\
\text { census since } 1950\end{array}$ \\
\hline Canada & 1951 & 4 & $5.3 \%$ & $94.7 \%$ & Metropolitan areas over $1,000,000$ \\
\hline Western Europe & 1965 & 42 & $-13.0 \%$ & $113.0 \%$ & Metropolitan areas over $1,000,000$ \\
\hline Japan & 1965 & 8 & $7.6 \%$ & $92.4 \%$ & Metropolitan areas over $1,000,000$ \\
\hline Australia \& New Zealand & 1965 & 6 & $7.2 \%$ & $92.8 \%$ & Metropolitan areas over $1,000,000$ \\
\hline Hong Kong & 1965 & 1 & $55.5 \%$ & $44.5 \%$ & Metropolitan areas over $1,000,000$ \\
\hline Israel & 1965 & 1 & $-1.6 \%$ & $101.6 \%$ & Metropolitan areas over $1,000,000$ \\
\hline Total & & 114 & $5.6 \%$ & $94.4 \%$ & \\
\hline
\end{tabular}

Source: http://www.demographia.com/db-highmetro.htm

1) For Seoul metropolitan area. Incheon Metropolitan city (excluding Ganghwa-gun and Ongjin-gun) is also considered as a central city.

2) Four cities and counties (Jinhae-si, Yangsan-si, and Gijang-gun) are considered as the suburbs of Busan metropolitan area. 
Figure 1. U.S. Public Transport Market Share and Subsidies, 1970-2006

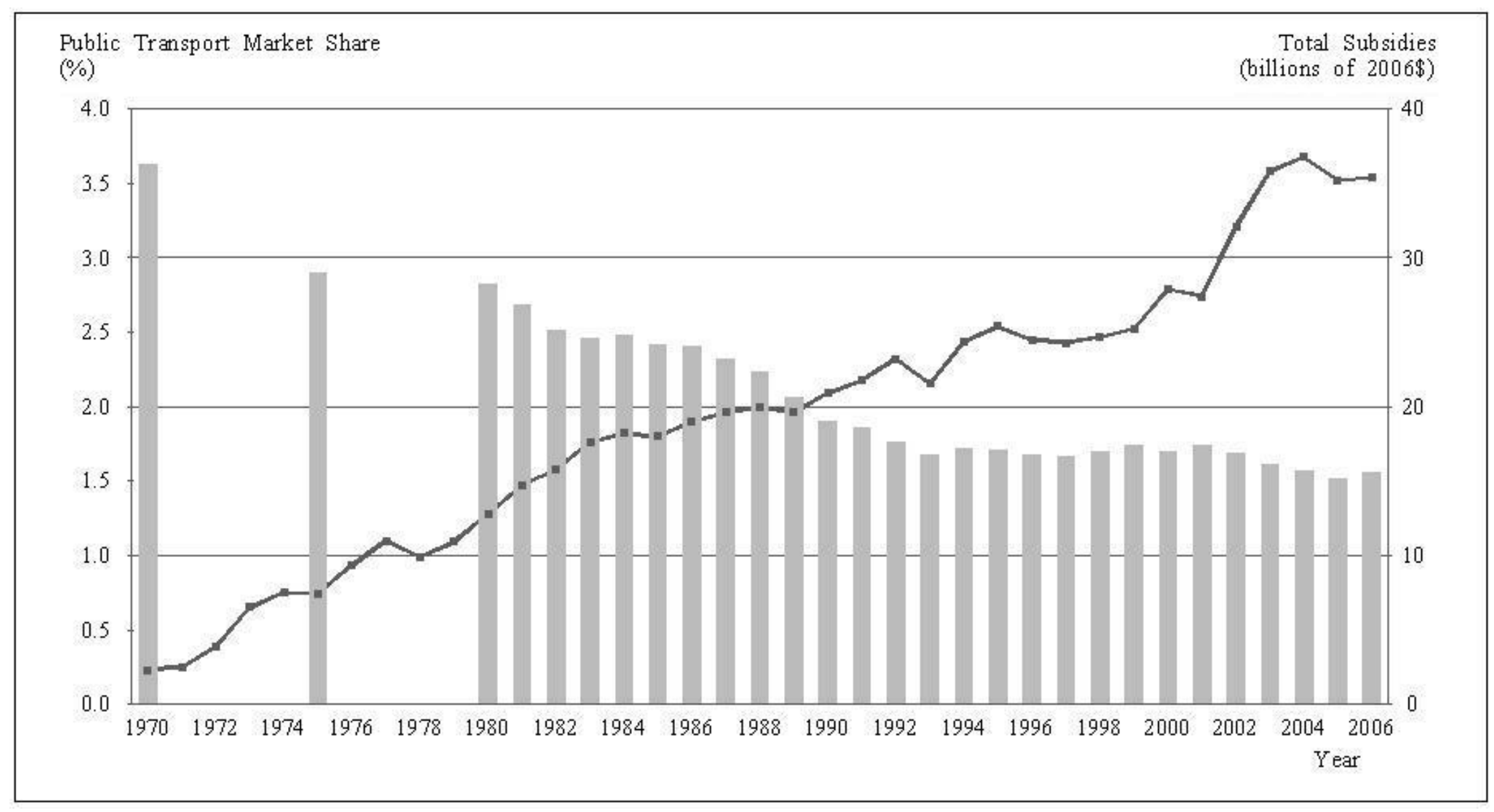

Source. Public Transport Market Share, http://www.publicpurpose.com/ut-usptshare45.pdf 
Figure 2: Commuting and Metro Size
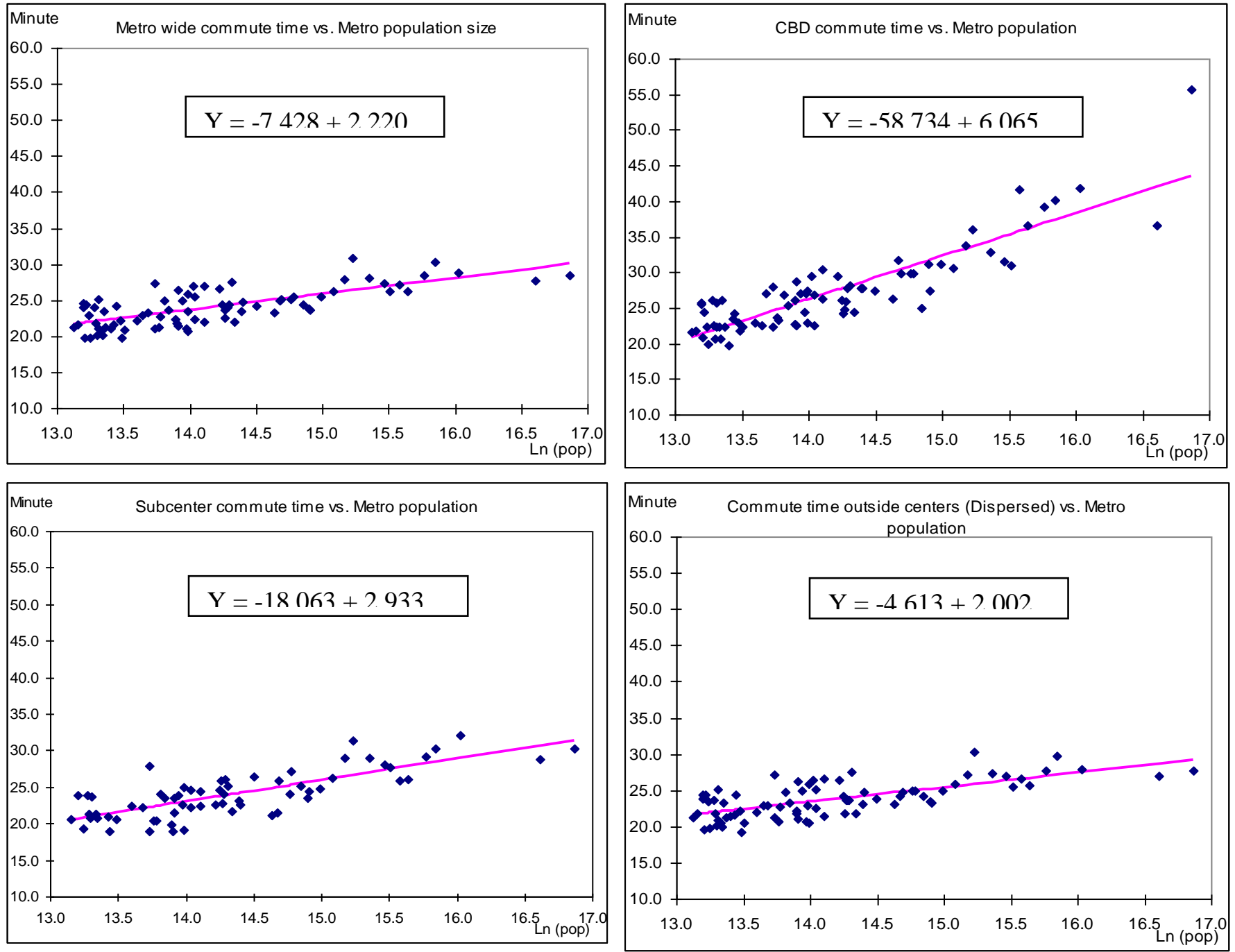

Source: Lee (2006) 
Figure 3: U.S. Moving Average Growth Rates, 1950-2007

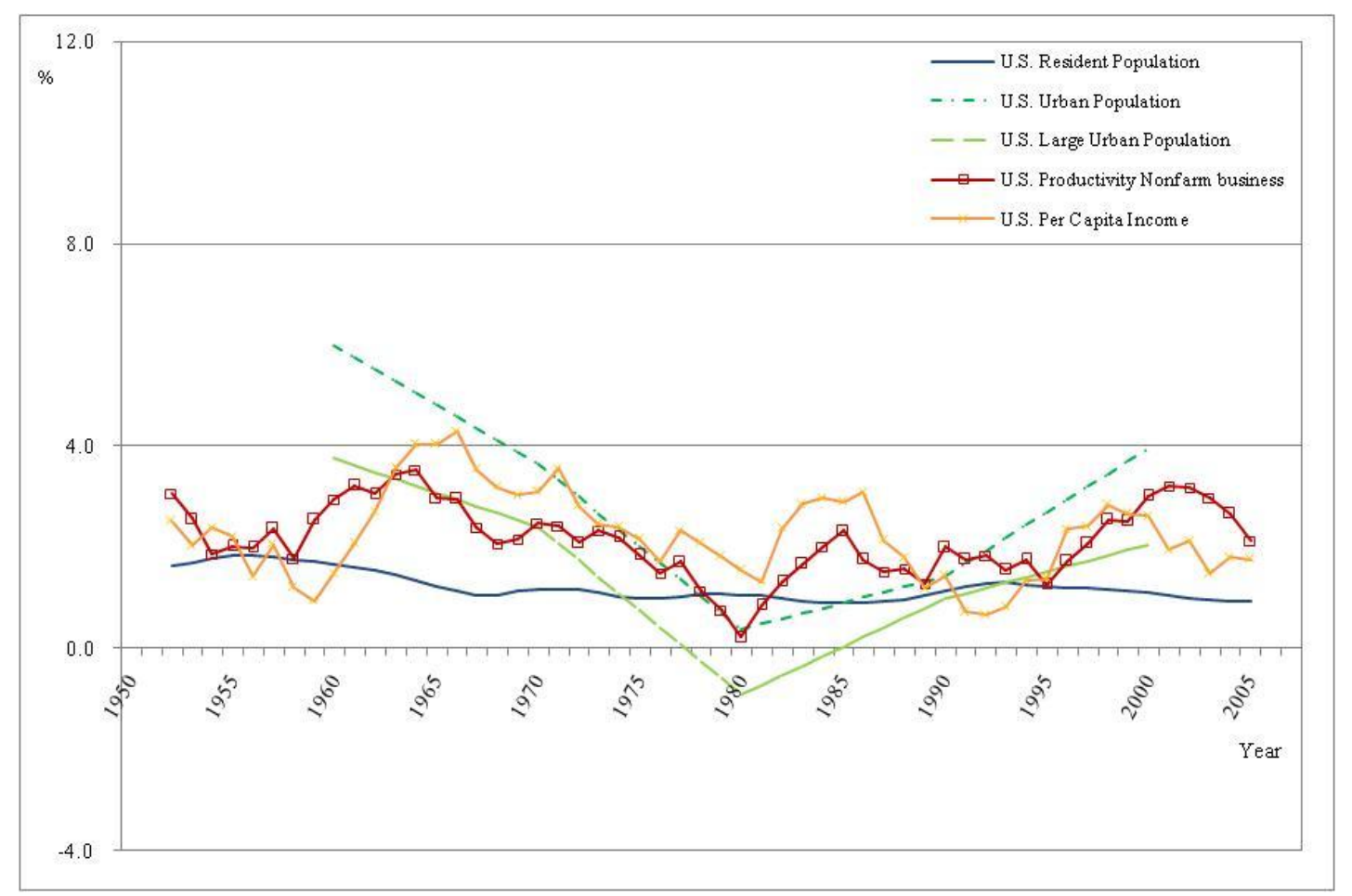

\section{Notes}

1. Trend of resident population, productivity growth, and per capita income growth is a five-year moving average of growth rates

2. Trend of urban and large urban population growth is not a moving average but trend of ten-year average growth rates from various decennial census reports.

3. Large urban areas refer to urban areas with at least 1,000,000 population.

Sources: U.S. Census Bureau, Demographia, U.S. Bureau of Labor Statistics, U.S. Bureau of Economic Analysis.

Data for resident population, http://www.census.gov/compendia/statab/tables/09s0002.xls

Data for urban population, http://demographia.com/db-1945uza.htm

Data for large urban population, http://www.demographia.com/db-uza2000.htm

Data for productivity index, http://www.bls.gov/data/\#productivity

Data for per capita disposable income, http://www.bea.gov/national/nipaweb/TableView.asp?Select

Table $=58 \&$ Freq $=$ Qtr $\&$ First Year $=2006 \&$ Last Year $=2008$ 
Figure 4: 100-Year U.S. GDP per capita growth trend

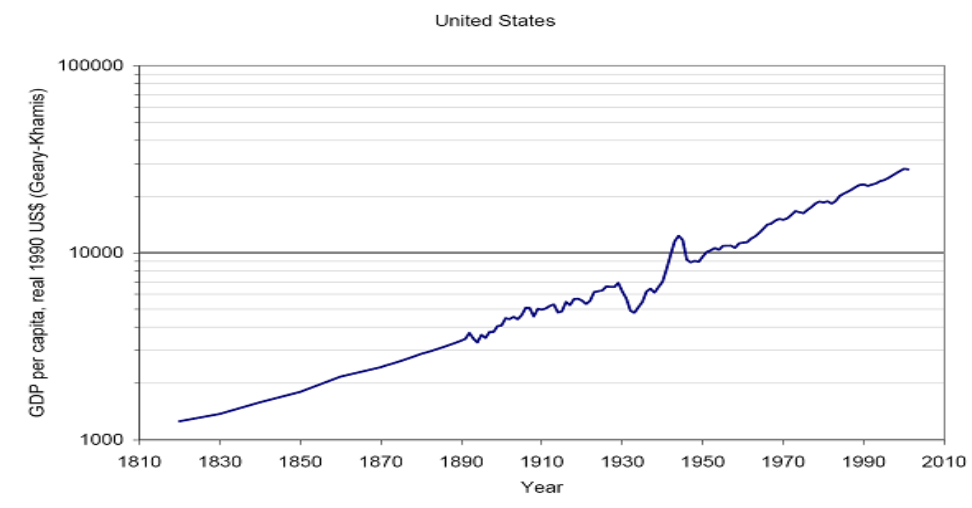

Source: Jones (2002) 


\section{REFERENCES}

Altshuler, Alan (1979) The Urban Transportation System: Politics and Policy Innovation. Cambridge, MA: The MIT Press.

Alonso, William (1971): “The Economics of City Size” Papers of the Regional Science Association, 26, 71-83.

Alonso, William (1973) “Urban zero population growth” Daedalus 102:4, 191-206

Audretsch, David B. and Maryann P. Feldman (2003) "Knowledge Spillovers and the Geography of Innovation."

Baldwin, Richard E. and Philippe Martin (2004) “Agglomeration and regional growth" in Vernon Henderson and Jacques-Francois Thisse, Handbook of Regional and Urban Economics: Cities and Geography.

Banfield, Edward C. (1982) “The Zoning of Enterprise” Cato Journal 2:2 (Fall).

Bertaud, Alain (2004) "The spatial organization of cities: Deliberate outcome or unforeseen consequences?" WP 
Burchell, Robert (1998) The Costs of Sprawl-Revisited. Transportation Cooperative Research Program Report 39. Washington, D.C.: National Academy Press.

Bruegmann, Robert (2005) Spawl: A Compact History. Chicago: University of Chicago Press.

Carlino, Gerald A. (2000) "From Centralization to Deconcentration: People and Jobs Spread Out" Federal Reserve Bank of Philadelphia Business Review (November/December) 15-27.

Ciccone, Antonio and Robert E. Hall (1996) "Productivity and the Density of Economic Activity" National Bureau of Economic Research Working Paper \#4313. NBER: Cambridge, MA.

Crane, Randall, and Daniel Chatman (2003) “Traffic and sprawl: Evidence from U.S. commuting, 1985

to 1997" Planning and Markets 6 (1):14-22.

Demographia (2008) http://www.demographia.com/d-new.htm

Dixit, Avinash (2009) "Governance Institutions and Economic Activity” American Economic Review 99:1, 5-24.

Downs, Anthony (1999), "Some Realities about Sprawl and Urban Decline," Housing Policy Debate, 10, 955-974. 
Dumais, Guy, Glenn Ellison and Edward L. Glaeser (2002) "Geographic Concentration as a Dynamic Process" The Review of Economics and Statistics, 94:2, 193-204.

Durlauf, Steven N. (2004) "Neighborhood Effects" in Vernon Henderson and Jacques-Francois Thisse, Handbook of Regional and Urban Economics: Cities and Geography.

Epstein, Richard A. (2008) "Public Use in a Post-Kelo World" Supreme Court Economic Review, Vol 17.

Ewing, R., T. Schmid, R. Killingsworth, A. Zlot and S. Raudenbush (2003), "Relationship Between Urban Sprawl and Physical Activity, Obesity and Morbidity," The Science of Health Promotion, 18, \#147.

Fischel, William A. (2004) “An Economic History of Zoning and a Cure for its Exclusionary Effects" Urban Studies 41:2, 317-340.

Florida, Richard and Tim Gulden and Charlotta Mellander (2007) “The Rise of the Mega Region" Working Paper, University of Toronto, Joseph L. Rotman School of Management.

Garreau, Joel (1991) Edge City: Life on the New Frontier. New York: Doubleday. 
Giuliano, Genvieve, and Christian Redfearn, Ajay Agarwal and Sylvia He (2009) "Network Accessibility and the Evolution of Urban Employment" presented at the $48^{\text {th }}$ annual meetings of the Western Regional Science Association, Napa, California.

Glaeser, Edward L. and Joseph Gyourko (2008a) Rethinking Federal Housing Policy. Washington, DC: The AEI Press.

Glaeser, Edward L. and Matthew E. Kahn (2003) "Sprawl and Urban Growth"

Glaeser, Edward L. and Heidi D. Kallal, Jose A. Scheinkmann and Andrei Shleifer (1992) "Growth in Cities" The Journal of Political Economy, 100:6, 1126-1152.

Gordon, Peter, Bumsoo Lee, James. E. Moore II, and Harry. W. Richardson, “Commuting Trends in U.S. Cities in the 1990s" (2009) Journal of Planning Education and Research, 19:1, 78-89.

Gordon, Peter, Harry W. Richardson and Ajay Kumar (1989), "The Spatial Mismatch Hypothesis: Some New Evidence,” Urban Studies, 26, 315-26.

Harris, Timothy F. and Yannis M. Ionnides (2000) "Productivity and Metropolitan Density" WP. 
Head, Keith and Thierry Mayer (2003) "The Empirics of Agglomeration and Trade" in the Handbook of Urban and Regional Economics, vol. 4.

Henderson, Vernon (1994) Externalities and Industrial Development. NBER WP No. 4730.

Ingram, Gregory K. (2007) “Appreciating Density” Land Lines Cambridge, MA: Lincoln Institute of Land Policy (April), p.1

Izraeli, O., and T. R. McCarthy.(1985) "Variations in Travel Distance, Travel Time and Modal Choice Among SMSAs" Journal of Transport Economics and Policy 19 (2):139-160.

Jackson, Kenneth T. (1985) The Crabgrass Frontier: The Suburbanization of the U.S. New York: Oxford University Press.

Jacobs, Jane (1961) The Death and Life of Great American Cities. New York: Vintage Books.

Jones, Charles I. (2002) "Sources of U.S. Economic Growth in a World of Ideas" The American Economic Review, 92:1, 220-239.

Kahn, Matthew E. (2008) "New Evidence on Trends in the Cost of Urban Agglomeration" National Bureau of Economic Research Working Paper. http://www.nber.org/chapters/c7988.pdf 
Kneebone, Elizabeth (2009) “Job Sprawl Revisited: The Changing Geography of Metropolitan Employment” Washington DC: Metropolitan Policy Program at Brookings (April).

Kuntsler, James H. (1996) “Home from Nowhere” The Atlantic 278:3, 43-66.

Krugman, Paul (2009) “The Increasing Returns Revolution in Trade and Geography” American Economic Review, 99:3, 561-571.

Ladd, Helen F. (1992) "Population Growth: Density and the Costs of Providing Public Services" Urban Studies, 29:2, 273-295.

Leamer, Edward E. (2009) Macroecononomic Patterns and Stories. Berlin: Springer.

Lee, Bumsoo. (2007) "Edge or edgeless cities? Urban spatial structure in U.S. metropolitan areas, 1980 to 2000," Journal of Regional Science 47:3, 479-515.

Lee, Bumsoo and Peter Gordon (2006) "Urban Spatial Structure and Economic Growth in U.S. Metropolitan Areas" presented at the $46^{\text {th }}$ annual meetings of Western Regional Science Association , Newport Beach, CA

Lindsey, Brink (2007) The Age of Abundance. New York: Harper-Collins. 
Lucas, Robert (1988) “On the Mechanics of Economic Development” Journal of Monetary Economics, 22:1, 3-42.

Marshall, Alfred (1890) Principles of Economics London: Macmillan.

Moretti, Enrico (2003) "Human Capital Externalities in Cities" in the Handbook of Urban and Regional Economics, vol. 4.

Ottaviano, Gianmarco and Jacques-Francois Thisse (2004) “Agglomeration and Economic Geography," in J.Vernon Henderson and Jacques-Francois Thisse, eds., Handbook of Urban and Regional Economics. Amsterdam: Elsevier.

Pisarski, Alan E. (2007) "Commuting in America" Issues in Science and Technology (Winter).

Quigley, John M. (1998) “Urban Diversity and Economic Growth” The Journal of Economic Perspectives, 12:2, 127-138.

Richardson, Harry W. and Peter Gordon, Myung-jin Jun, Moon Kim (1993) "Pride and Prejudice: The Economic Impacts of Growth Controls in Pasadena" Environment and Planning A 25: 9871002.

Ricketts, Martin (2008) “The Economic Analysis of Institutions” Economic Affairs, 28:3, 2-6. 
Rosenthal, Stuart S. and William C. Strange (2003) "Evidence on the Nature and Sources of Agglomeration Economies" in the Handbook of Urban and Regional Economics, vol. 4.

Sarzynski, Andrea, Harold L. Wolman, George Galster, and Royce Hanson. (2006) “Testing the conventional wisdom about land use and traffic congestion: The more we sprawl, the less we move?" Urban Studies 43 (3):601-626.

Schweitzer, Lisa and Jianping Zhou (2009) "Growing Smart about Air Quality” Working paper, METRANS, University of Southern California.

Todorovich, Petra "Introduction" in Keith S. Goldfeld (ed.) (2008) The Economic Geography of Megaregions. Princeton: Princeton University Press.

U.S. Bureau of Economic Analysis (2009)

http://www.bea.gov/national/nipaweb/SelectTable.asp?Popular=Y

U.S. Census Bureau (2008) The 2009 Statistical Abstract.

http://www.census.gov/compendia/statab/ 
U.S. Department of Labor (2009)

http://data.bls.gov/PDQ/servlet/SurveyOutputServlet?data_tool=latest_numbers\&series_id=PRS 85006092

Webster, Chris and Lawrence and Wai-Chung Lai (2003) Property Rights, Planning and Markets. London: Edward Elgar.

Windsor, Dwayne (1979) “A Critique of 'The Costs of Sprawl”” Journal of the American Planning Association. 45:3, 279-292.

Whyte, William H., Jr. (1958) "Urban Sprawl” in The Exploding Metropolis: A Study of the Assault on Urbanism and How Our Cities Can Resist It, Editors of Fortune. Garden City, N.J.: Doubleday Anchor Books. 
